\title{
A Semantic Study of the Translation of Homonymous Terms in Sacred Texts: the Qur'an in focus
}

\author{
Hossein Vahid Dastjerdi \& Bahareh Zamani
}

University of Isfahan

\begin{abstract}
Homonymy, as a feature of semantics, presents a challenge for translators. It has actually been argued that homonymous terms might give rise to serious problems in translation, since their occurrence in a sentence can result in a certain amount of ambiguity. On this basis, the present study aims at providing a short overview of the main theoretical issues concerning homonymy, identifying a limited number of homonymous terms in the Qur'an along with their equivalents in five well-known English renderings of this sacred Scripture, and discovering the strategies for the translation of this feature as well as determining the extent of translators' success in avoiding ambiguity they face in performing the translation task in this respect.
\end{abstract}

Keywords: homonymy, semantics, ambiguity, primary meaning, sacred texts

\section{Introduction}

According to Palmer (1970), although the term 'semantik' occurred 
once in the seventeenth century, 'semantics' did not occur until 1894 when it was introduced in a paper entitled 'Reflected Meaning: a Point in Semantics'. In this case the term was not used simply to refer to meaning, but to its development. The outset of the nineteenth century witnessed the publication of the book 'Semantics: Studies in the Science of Meaning', in which 'semantics' was treated as the science of meaning and it was actually the first time when semantics was used in its modern sense (1). Nowadays, 'semantics' is used as a technical term meaning "the study of the meaning of words, phrases, and sentences" (Yule 1996: 114). It differs from 'pragmatics' in that semantic analysis focuses on what the words conventionally mean rather than on what a speaker might want the words to mean. As a result of semantic analysis, 'lexical relations' among words can be determined. 'Lexical relations' refer to the relations among words based on their meaning. There are some occasions in which the speakers of a particular language give the meaning of words in terms of their relationship not in terms of their component features. One of the main categories of lexical relations which is the focus of the present study is 'homonymy'.

\subsection{Homonymy}

Different theorists have proposed a variety of definitions for the term 'homonymy'. As an example, Fromkin (1988: 122) defines homonymy as "two or more words with identical phonological forms, but with different meanings." Palmer (1970: 101), as a pioneer, refered to homonymy as a case in which "there are several words with the same shape," and Yule (1996: 121) defines it as follows:

The term homonymy is used when one form (written and spoken) has two or more unrelated meanings. Homonyms are words which have quite separate meanings, but which have accidentally come to have exactly the same form. 
According to Carter (1997), if the reader or listener can not identify the intended meaning of a homonym, it may result in 'lexical ambiguity'. A word or phrase is ambiguous if it can be understood or interpreted in more than one way. Thus, sentences may be ambiguous because they contain one or more homonymous words. This condition is called 'lexical ambiguity' (Fromkin 1988: 211). Ambiguity which is the most immediate entailment of using homonymy in discourse and, as a result, causes obstacles in the process of translation will be elaborated in the following section.

\subsection{Ambiguity}

Empson (1961: 5) defines ambiguity as "an indecision as to what you mean, an intention to mean several things, a probability that one or other or both of two things has been meant, and the fact that a statement has several meanings." Newmark (1988: 218) takes ambiguity in the sense of "a stretch of SL text, normally a word or a syntactic structure, having apparently more than one meaning, in or in spite of its context." According to Salehi (1996: 173), the term ambiguity refers to "the words, phrases, sentences, or statements which cover two or more meanings where just one of them has been intended."

Ambiguity is a linguistic feature which has been divided into different types. One of the most well-known classifications of ambiguity is that of Newmark (1988). He distinguishes seven types of ambiguity as follows:

\subsubsection{Grammatical ambiguity}

This kind of ambiguity is the result of a sentence being syntactically ambiguous within its context. It may be poorly written and if the context is informative enough, it can be disambiguated (e.g. the shooting of the hunters or flying planes can be dangerous). 


\subsubsection{Lexical ambiguity}

Lexical ambiguity is both more common and more difficult to clear up than grammatical ambiguity. Words may have numerous senses and the senses may be close to or remote from each other. Sometimes a word has two senses which are equally effective in the relevant stretch of language; i.e. sometimes, as in the case of metaphorical and literal sense of a word, one may interpret it with its both senses in mind. For example, the Persian term "نقاشي" (naqqāshi) may be interpreted literally as 'painting' and metaphorically as “زيبازي" (zibā), i.e. 'a beautiful object'.

\subsubsection{Pragmatic ambiguity}

This type of ambiguity arises when the tone or the emphasis in an SL sentence is not clear. As an example, the emphasis of a sentence such as "I'm working here today", can only be perceived, if at all, from its context, although italics for one word would help.

\subsubsection{Cultural ambiguity}

This kind of ambiguity arises if a cultural feature is changed in terms of its function. Newmark advises translators to establish the intended sense of that misused word from the context and translate it accordingly.

\subsubsection{Idiolectal ambiguity}

Newmark points out that some people use some words in a sense peculiar to themselves because they have heard them in many situations, but have never looked them up in a dictionary or because they feel a lexical gap in their language and fill it with an inappropriate word (e.g. some think 'Jesuitical' means 'turning 
criticism to one's own advantage' rather than 'casuistical'). This he names 'idiolectal ambiguity'.

\subsubsection{Referential ambiguity}

This kind of ambiguity appears when the use of a word, phrase or sentence prompts two or more images of the reality the translator is trying to describe. For example, if somewhere earlier in the text it has been pointed out that the story took place in a village, the term 'country' in the sentence "I've a mighty notion to just leave the country for good and all." refers to روستا (rūstā = village) not كثور (keshvar= country). In a sense it can be said that all ambiguity is referential.

\subsubsection{Metaphorical ambiguity}

This kind of ambiguity is the result of a metaphorical expression which prompts more than one meaning, of which only one is intended. Newmark's suggestion in such cases is to translate the most probable sense and to put in a footnote the less probable sense if it is important (218-220).

\subsection{Translation of Ambiguity}

Empson (1961: 5) asserts that in a sense all words have a number of meanings of which none can be reduced to a finite number of points, "and if they could, the points can not be conveyed by words." He continues:

Thus a word may have several distinct meanings, several meanings connected with one another; several meanings which unite together so that the word means one relation or one process...it is useful to be able to separate these if you 
wish, but it is not obvious that in separating them at any particular point you will not be raising more problems than you solve.

In line with Empson and in connection with translation, Newmark (1988) believes that most sentences comprise a deal of lexical and grammatical ambiguity which may be linguistic or referential and all this ambiguity will be cleared up by the micro- and the macro context. But if ambiguity remains, the translator has to determine whether it is referential or linguistic. A referential ambiguity must be retained and pointed out, if it can not be cleared up by the translator. A linguistic ambiguity may enrich the text when both meanings are intended, and the translator should attempt to reproduce it, but if $s /$ he is unable to do so, just one of the meanings must be translated.

\section{Method}

In the present study, the ways in which different translators have dealt with homonyms in the Qur'an are compared and contrasted. As such, firstly, a number of Qur'anic homonyms and their meanings are selected from the reference books, 'Semantic Aspects of the Qur'an' (Teflisi 1960) and 'A Dictionary and Glossary of the Koran' (Penrice 1971). Then, the verses containing such words are extracted from the original Arabic text of the Scripture. As a next step, the English equivalents of such homonyms are identified in five English versions of the Book translated by Shakir (1985), Tr1; Yusuf Ali (1990), Tr2; Pickthall (1990), Tr3; Al-Hilali \& Mohammad Muhsen Khan (1995), Tr4; and Saffarzadeh (2001), Tr5. Finally, the equivalents used by these translators are examined to see to what extent they have been successful in conveying them to the target language and tackling possible ambiguities. 


\section{Elicitation and Analysis of Data}

To begin with, from among so many homonymous terms in the Qur'an, only five homonyms are considered in the present study;

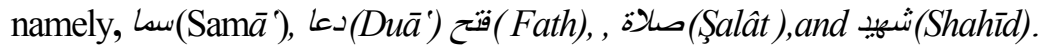

\section{1. سماء (Samāe}

The first homonymous term is سماء (Samāe). This term has been used in its four different meanings in the Qur'an, i.e. 'sky', 'cloud', 'rain' and 'ceiling' (Teflisi 1960: 134 \& Penrice 1971: 72).

Table 1. Equivalents of the Term سماء (Samāe) in Five English Versions

\begin{tabular}{llllll} 
Meaning & tr1 & tr2 & tr3 & tr4 & tr5 \\
\hline 1. sky & heaven & heaven & heaven & heaven & heaven \\
2. cloud & cloud & sky & sky & sky & sky \\
3. rain cloud & rain & sky & rain & rain \\
4. ceiling & ceiling & ceiling & roof (of his dwelling) & ceiling & ceiling
\end{tabular}

As regards the first meaning 'sky', used in the following verse, Table 1 shows that all translators have successfully selected the exact equivalent, i.e. 'heaven'.

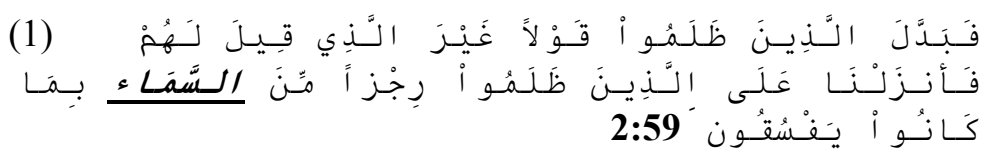

[Shakir] But those who were unjust changed it for a saying other than that which had been spoken to them, so We sent upon those who were unjust a pestilence from heaven, because they transgressed. [Yusuf Ali] But the transgressors changed the word from that which 
had been given them; so We sent on the transgressors a plague from heaven, for that they infringed (Our command) repeatedly.

[Pickthal] But those who did wrong changed the word which had been told them for another saying, and We sent down upon the evildoers wrath from heaven for their evil-doing.

[Al-Hilali] But those who did wrong changed the word from that which had been told to them for another, so We sent upon the wrong-doers Rijzan (a punishment) from the heaven because of their rebelling against Allah's Obedience.

[Saffarzadeh] (but) the evildoers changed the word (and substituted an irrelevant word) for that which had been spoken to them. So we sent down upon the evildoers a plague from the heaven, due to their rebellion against Allah's commands.

Regarding the second meaning 'cloud', used in the following verse, only T1 has used its correct English equivalent, while others have used the primary meaning of سماء (Samāe), i.e. 'sky'.

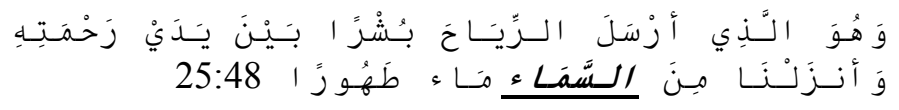

[Shakir] And He it is Who sends the winds as good news before His mercy; and We send down pure water from the cloud,

[Yusuf Ali] And He it is Who sends the winds as heralds of glad tidings, going before His mercy, and We send down pure water from the sky, [Pickthal] And $\mathrm{He}$ it is Who sendeth the winds, glad tidings heralding His mercy, and We send down purifying water from the sky, [Al-Hilali]And it is $\mathrm{He}$ Who sends the winds as heralds of glad tidings, going before His Mercy (rain), and We send down pure water from the sky,

[Saffarzadeh] and Allah is the Grace-Bestower who sent the winds as heralds before the rain and We sent down pure water from the sky. 
As to the third meaning 'rain' used in the following verse, Table1 above shows that only translators 2,4 , and 5 have used the term 'rain', the exact equivalent.

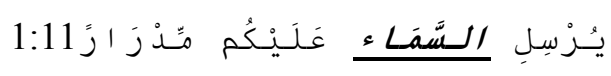

[Shakir] He will send down upon you the cloud, pouring down abundance of rain.

[Yusuf Ali] He will send rain to you in abundance;

[Pickthal ] He will let loose the sky for you in plenteous rain, [Al-Hilali] He will send rain to you in abundance; [Saffarzadeh] and then he will send rain to your lands in abundance.

Finally, all translators but T3 have used the correct equivalent for the last meaning, i.e. 'ceiling' as intended in the following verse:

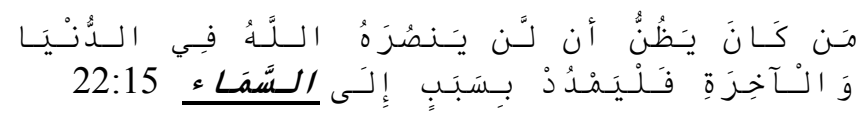

[Shakir] Whoever thinks that Allah will not assist him in this life and the hereafter, let him stretch a rope to the ceiling, then let him cut (it) off, then let him see if his struggle will take away that at which he is enraged.

[Yusuf Ali] If any think that Allah will not help him (His Messenger) in this world and the Hereafter, let him stretch out a rope to the ceiling and cut (himself) off: then let him see whether his plan will remove that which enrages (him)!

[Pickthal] Whoso is wont to think (through envy) that Allah will not give him (Muhammad) victory in the world and the Hereafter (and is enraged at the thought of his victory), let him stretch a rope up to the roof (of his dwelling), and let him hang himself. Then let him see whether his strategy dispelleth that whereat he rageth! 
54 A Semantic Study of the Translation of Homonymous Terms

[Al-Hilali] Whoever thinks that Allâh will not help him (Muhammad) in this world and in the Hereafter let him stretch out a rope to the ceiling and let him strangle himself. Then let him see whether his plan will remove that whereat he rages!

[Saffarzadeh]If someone thinks that Allah will not help him in this world and in the Hearafter, he could raise himself by a rope to the ceiling of his home and then cut himself off to see if by committing suicide he overcomes his senseless anger? (a person who has no hope in Allah's mercy and Grace ,he is indeed a disbeliever).

\section{2. دعا (Duāe)}

Here we consider the next homonym دعا (Duāe) with its six different meanings located in various verses of the Qur'an, i.e. 'prayer', 'worship', 'call', 'seeking help', 'asking', and 'requesting' (Teflisi 1960: 98-100; Penrice 1971: 48).

Table 2. Equivalents of the Term دعا (Duāe) in Five English Versions

\begin{tabular}{llllll} 
Meaning & $\operatorname{tr} 1$ & $\operatorname{tr} 2$ & $\operatorname{tr} 3$ & tr4 & tr5 \\
\hline 1. prayer & cry & cry & prayer their way of request & prayer \\
2. worship & call & call & cry & invoke & worship \\
3. call & call & call & call & call & call \\
4. seeking help call & call & call & call & call \\
5. asking & call on beseech pray & call upon & beseech \\
6. requesting & pray & call & pray invoke & pray
\end{tabular}

In the case of the first meaning 'prayer', used in the following verse, Table 2 above shows that only translators 3 and 5 have used the correct equivalent.

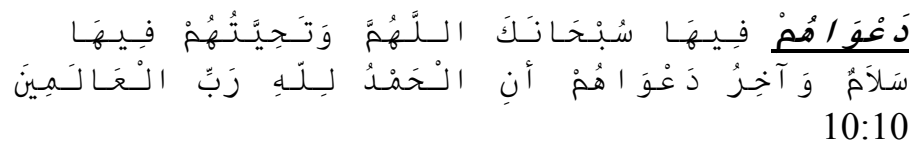


[Shakir] Their cry in it shall be: Glory to Thee, O Allah! and their greeting in it shall be: Peace; and the last of their cry shall be: Praise be to Allah, the Lord of the worlds.

[Yusuf Ali] (This will be) their cry therein: "Glory to Thee, O Allah!" And "Peace" will be their greeting therein! And the close of their cry will be: "Praise be to Allah, the Cherisher and Sustainer of the worlds!"

[Pickthal] Their prayer therein will be: Glory be to Thee, O Allah! and their greeting therein will be: Peace. And the conclusion of their prayer will be: Praise be to Allah, Lord of the Worlds!

[Al-Hilali] Their way of request therein will be Subhânaka Allâhumma (Glory to You, O Allâh!) and Salâm (peace, safe from each and every evil) will be their greetings therein (Paradise)! and the close of their request will be: Al-Hamdu Lillâhi Rabbil-'Alamîn [All the praises and thanks are to Allâh, the Lord of 'Alamîn (mankind, jinns and all that exists)].

[Saffarzadeh] (in the gardens) their prayer will be: "O, Allah! Absolute purity is yours." And their greeting will be Salam and they end their prayer saying:

"Thanksgiving and adoration is due only to Allah, the Creator of the worlds."

Regarding the second meaning 'worship', used in the following verse, only T5 has employed the exact English equivalent.

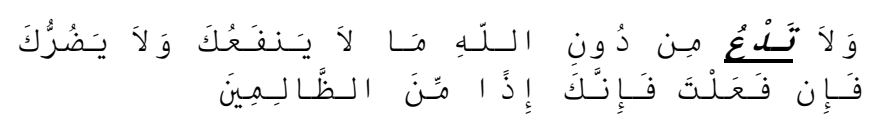

[Shakir] And do not call besides Allah on that which can neither benefit you nor harm you, for if you do then surely you will in that case be of the unjust.

[Yusuf Ali] "“Nor call on any, other than Allah; - Such will neither profit thee nor hurt thee: if thou dost, behold! thou shalt certainly be 
of those who do wrong.",

[Pickthal] And cry not, beside Allah, unto that which cannot profit thee nor hurt thee, for if thou didst so then wert thou of the wrongdoers.

[Al-Hilali] "And invoke not besides Allâh, any that will neither profit you, nor hurt you, but if (in case) you did so, you shall certainly be one of the Zâlimûn (polytheists and wrong-doers)."

[Saffarzadeh] "and do not worship instead of Allah those which neither profit you nor harm you; if you do so you shall certainly be of those who do wrong."

As regards the third meaning 'calling', used in the following verse, Table 2 shows that all translators have been successful in transferring it to the target language.

(7) $21: 45$
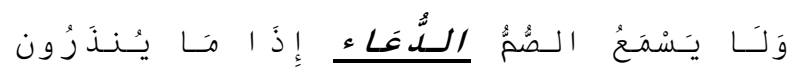

[Shakir] Say: I warn you only by revelation; and the deaf do not hear the call whenever they are warned.

[Yusuf Ali] Say, "I do but warn you according to revelation": But the deaf will not hear the call, (even) when they are warned!

[Pickthal] Say (O Muhammad, unto mankind): I warn you only by the Inspiration. But the deaf hear not the call when they are warned. [Al-Hilali] Say (O Muhammad): "I warn you only by the revelation (from Allâh and not by the opinion of the religious scholars and others). But the deaf (who follow the religious scholars and others blindly) will not hear the call, (even) when they are warned [(i.e. one should follow only the Qur'an and the Sunnah (legal ways, orders, acts of worship, statements of Prophet Muhammad, as the Companions of the Prophet did)].

[Saffarzadeh] say (o, Messenger!): "I only warn you according to what is revealed to me" but the deaf do not hear the call when they are warned. 
None of the translators has, however, been attentive to choose the exact equivalent for the forth meaning, 'seeking help', as it is used in the following verse of the Writ.

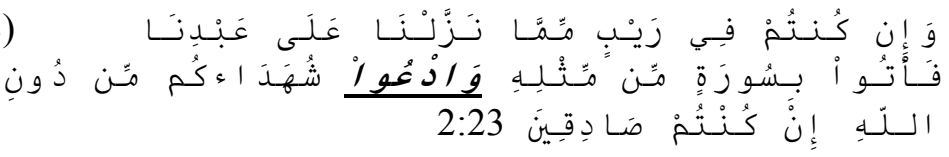

[Shakir] And if you are in doubt as to that which We have revealed to Our servant, then produce a chapter like it and call on your witnesses besides Allah if you are truthful.

[Yusuf Ali] And if ye are in doubt as to what We have revealed from time to time to Our servant, then produce a Sura like thereunto; and call your witnesses or helpers (If there are any) besides Allah, if your (doubts) are true.

[Pickthal] And if ye are in doubt concerning that which We reveal unto Our slave (Muhammad), then produce a surah of the like thereof, and call your witness beside Allah if ye are truthful.

[Al-Hilali] And if you (Arab pagans, Jews, and Christians) are in doubt concerning that which We have sent down (i.e. the Qur'ân) to Our slave (Muhammad Peace be upon him), then produce a Sûrah (chapter) of the like thereof and call your witnesses (supporters and helpers) besides Allâh, if you are truthful.

[Saffarzadeh] and if you are in doubt (regarding the truth) as to what We have revealed to our obedient worshipper(Mohammad the Messenger of Allah),then produce a Surah similar (to that of the Qur'an) and call your witnesses apart from Allah, (Who is Powerful and Able to create everything), if you are telling the truth;

As regards the fifth meaning, 'asking', used in the following verse, only the first and the fourth translators have used its precise equivalent, i.e. 'call on /upon'. 
(9)

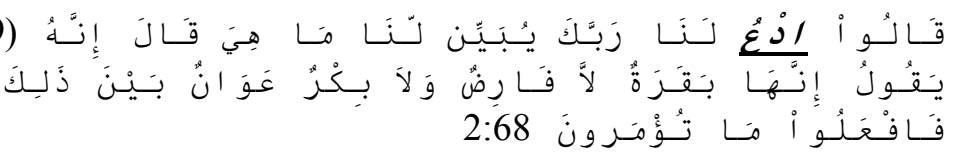

[Shakir] They said: Call on your Lord for our sake to make it plain to us what she is. Musa said: He says, Surely she is a cow neither advanced in age nor too young, of middle age between that (and this); do therefore what you are commanded.

[Yusuf Ali] They said: "Beseech on our behalf Thy Lord to make plain to us what (heifer) it is!" He said; "He says: The heifer should be neither too old nor too young, but of middling age. Now do what ye are commanded!"

[Pickthal] They said: Pray for us unto thy Lord that He make clear to us what (cow) she is. (Moses) answered: Lo! He saith, Verily she is a cow neither with calf nor immature; (she is) between the two conditions; so do that which ye are commanded.

[Al-Hilali] They said, "Call upon your Lord for us that He may make plain to us what it is!" He said, "He says, "Verily, it is a cow neither too old nor too young, but (it is) between the two conditions', so do what you are commanded."

[Saffarzadeh] they said: "beseech your Creator \& Nurturer on our behalf to make plains to us what kind (of cow) it should be?" He said: "Allah states:a heifer which is neither too old nor too young, but of middling age; now do what you are Commanded!"

Finally, as Table 2 reveals, again none of the five translators has used the correct equivalent for the last meaning 'requesting' as intended in the following verse.

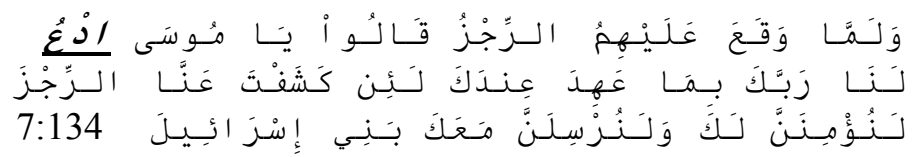


[Shakir] And when the plague fell upon them, they said: O Musa! pray for us to your Lord as $\mathrm{He}$ has promised with you, if you remove the plague from us, we will certainly believe in you and we will certainly send away with you the children of Israel.

[Yusuf Ali] Every time the penalty fell on them, they said: "O Moses! on your behalf call on thy Lord in virtue of his promise to thee: If thou wilt remove the penalty from us, we shall truly believe in thee, and we shall send away the Children of Israel with thee."

[Pickthal] And when the terror fell on them they cried: O Moses! Pray for us unto thy Lord, because He hath a covenant with thee. If thou removest the terror from us we verily will trust thee and will let the Children of Israel go with thee.

[Al-Hilali] And when the punishment fell on them they said: "O Mûsa (Moses)! Invoke your Lord for us because of His Promise to you. If you will remove the punishment from us, we indeed shall believe in you, and we shall let the Children of Israel go with you."

[Saffarzadeh] and whenever a plague fell upon them, they said: "O,Mussa! pray to your Creator \& Nurturer on our behalf, regarding his promise to you, if you remove the plague from us, we shall indeed believe in you, and we shall let the children of Israil go with you."

\section{3. فتح (Fath)}

According to Teflisi (1960: 215) and Penrice (1971: 107), and as it is shown in Table 3 below, the term فتح (Fath) has been used in the Qur'an in its five different meanings, i.e. 'Resurrection Day', 'judging', 'sending', 'opening' and 'help'. 
Table 3. Equivalents of the Term فتح (Fath) in Five English Versions

\begin{tabular}{llllll} 
Meaning & $\operatorname{tr} 1$ & $\operatorname{tr} 2$ & $\operatorname{tr} 3$ & $\operatorname{tr} 4$ & $\operatorname{tr} 5$ \\
\hline 1.Resurrection & day of & day of & day of & day of al-fath day of \\
Day & judgment & decision & the victory (decision) & victory \\
2.to judge & judge & decide & judge judge & judge \\
3.to send & let loose & let through let loose let loose & let loose \\
4.to open & be opened be opened be opened be opened & be opened \\
5.to help & victory & victory victory victory & victory
\end{tabular}

Regarding the first meaning 'resurrection day', used in the following verse, Table 3 shows that all translators but T3 and T5 have used the correct equivalent.

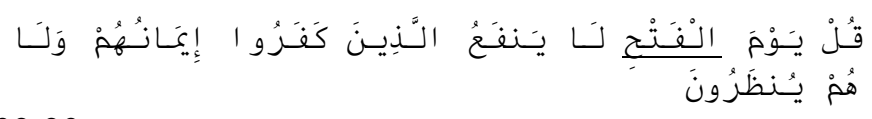

$32: 29$

[Shakir] Say: On the Day of Judgment the faith of those who (now) disbelieve will not profit them, nor will they be respited.

[Yusuf Ali] Say: "On the Day of Decision, no profit will it be to Unbelievers if they (then) believe! nor will they be granted a respite."

[Pickthal] Say (unto them): On the day of the victory the faith of those who disbelieve (and who then will believe) will not avail them, neither will they be reprieved.

[Al-Hilali] Say: "On the Day of Al-Fath (Decision), no profit will it be to those who disbelieve if they (then) believe! Nor will they be granted a respite."

[Saffarzadeh] say (O, Messenger!): "the Day of our victory will no profit their Faith for those who disbelieve now; and they will not be respited then to repent."

In the case of the second meaning, 'to judge', used in the following verse, only the second translator has been unsuccessful in selecting 
the exact equivalent.

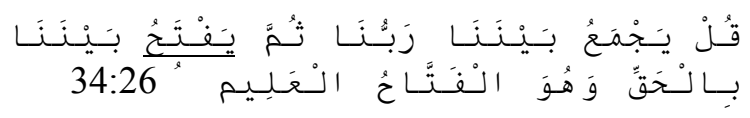

[Shakir] Say: Our Lord will gather us together, then will He judge between us with the truth; and $\mathrm{He}$ is the greatest Judge, the Allknowing.

[Yusuf Ali] Say: "Our Lord will gather us together and will in the end decide the matter between us (and you) in truth and justice: and He is the one to decide, the One Who knows all."

[Pickthal] Say: Our Lord will bring us all together, then He will judge between us with truth. He is the All-knowing Judge.

[Al-Hilali] Say: "Our Lord will assemble us all together (on the Day of Resurrection), then $\mathrm{He}$ will judge between us with truth. And $\mathrm{He}$ is the (Most Trustworthy) All-Knowing Judge."

[Saffarzadeh] Say(O, Messenger!): "Allah will gather all of us on the Day of Resurrection, then he will judge among us on the basis of the Truth, since He is the Knowing Judge." (and through His Embracing Knowledge He is aware of the deeds of all His creatures).

As regards the third meaning 'to send' used in the following verse, none of the translators has selected the exact equivalent.

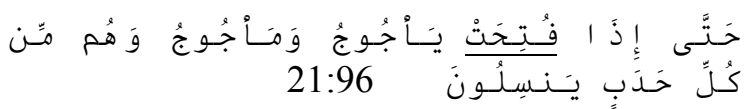

[Shakir] Even when Gog and Magog are let loose and they shall break forth from every elevated place.

[Yusuf Ali] Until the Gog and Magog (people) are let through (their barrier), and they swiftly swarm from every hill.

[Pickthal] Until, when Gog and Magog are let loose, and they hasten out of every mound, [Al-Hilali] Until, when Ya'jûj and Ma'jûj (Gog and Magog) are let loose (from their barrier), and they swiftly swarm from every mound. 
[Saffarzadeh] until when the Gog and Magog people are let loose (from the dam that Zulqarnin made) and pour down from the height of the loftiest mountains,

Considering the next meaning 'to open', used in the following verse, Table 3 shows that all translators have successfully selected the correct equivalent.

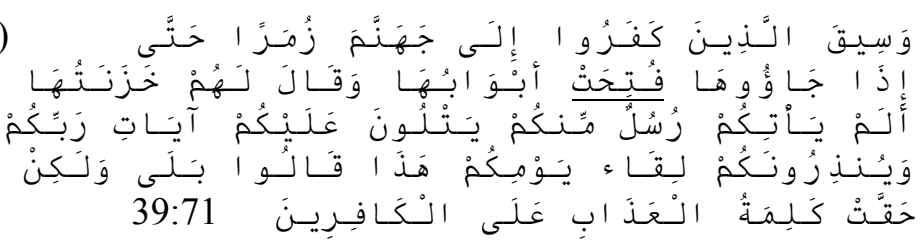

[Shakir] And those who disbelieve shall be driven to hell in companies; until, when they come to it, its doors shall be opened, and the keepers of it shall say to them: Did not there come to you messengers from among you reciting to you the communications of your Lord and warning you of the meeting of this day of yours? They shall say: Yea! But the sentence of punishment was due against the unbelievers.

[Yusuf Ali] The Unbelievers will be led to Hell in crowd: until, when they arrive, there, its gates will be opened. And its keepers will say, "Did not messengers come to you from among yourselves, rehearsing to you the Signs of your Lord, and warning you of the Meeting of This Day of yours?" The answer will be: "True: but the Decree of Punishment has been proved true against the Unbelievers!" [Pickthal] And those who disbelieve are driven unto hell in troops till, when they reach it and the gates thereof are opened, and the warders thereof say unto them: Came there not unto you messengers of your own, reciting unto you the revelations of your Lord and warning you of the meeting of this your Day? they say: Yea, verily. But the word of doom of disbelievers is fulfilled. 
[Al-Hilali] And those who disbelieved will be driven to Hell in groups, till, when they reach it, the gates thereof will be opened (suddenly like a prison at the arrival of the prisoners). And its keepers will say, "Did not the Messengers come to you from yourselves, reciting to you the Verses of your Lord, and warning you of the Meeting of this Day of yours?" They will say: "Yes, but the Word of torment has been justified against the disbelievers!"

[Saffarzadeh] the disbelievers will be driven to the hell in groups; and when they reach the Hell, its doors will be opened on them.

Finally, none of the translators has been successful in selecting the exact English equivalent for the last meaning 'to help', used in the following verse.

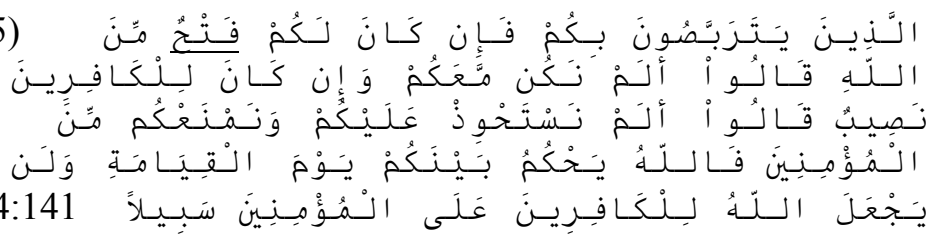

[Shakir] Those who wait for (some misfortune to befall) you then If you have a victory from Allah they say: Were we not with you? And there is a chance for the unbelievers, they say: Did we not acquire the mastery over you and defend you from the believers? So Allah shall Judge between you on the day of resurrection, and Allah will by no means give the unbelievers a way against the believers.

[Yusuf Ali] (These are) the ones who wait and watch about you: if ye do gain a victory from Allah, they say: "Were we not with you?"but if the unbelievers gain a success, they say (to them): "Did we not gain an advantage over you, and did we not guard you from the believers?" but Allah will judge betwixt you on the Day of Judgment. And never will Allah grant to the unbelievers a way (to triumphs) over the believers.

[Pickthal] Those who wait upon occasion in regard to you and, if a 
victory cometh unto you from Allah, say: Are we not with you? and if the disbelievers meet with a success say: Had we not the mastery of you, and did we not protect you from the believers? - Allah will judge between you at the Day of Resurrection, and Allah will not give the disbelievers any way (of success) against the believers.

[Al-Hilali] Those (hypocrites) who wait and watch about you; if you gain a victory from Allâh, they say: "Were we not with you," but if the disbelievers gain a success, they say (to them): "Did we not gain mastery over you and did we not protect you from the believers?" Allâh will judge between you (all) on the Day of Resurrection. And never will Allâh grant to the disbelievers a way (to triumph) over the believers. [Saffarzadeh] the (hypocrites)watch upon you: Then if there is a victory for you from Allah, they say: "were we not with you?"

\section{4. صلاة (Şalât)}

The next homonymous term is صلاة (Şalât).Teflisi (1960: 173-4) \& Penrice (1971: 85) assert that it has been used in the Qur'an in its seven different meanings, i.e. prayer, invocations, peace, blessing, religion, Qur'an recitation, synagogue.

Table 4. Equivalents of the Term صلاة (Şalât) in Five English Versions

\begin{tabular}{|c|c|c|c|c|c|}
\hline Meaning & $\operatorname{tr} 1$ & $\operatorname{tr} 2$ & $\operatorname{tr} 3$ & $\operatorname{tr} 4$ & $\operatorname{tr} 5$ \\
\hline 1.prayer & prayer & prayer & worship & al-salat & prayer \\
\hline 2.invocations & s pray & prayer & prayer & invocations & invocatio \\
\hline 3.peace & blessings & blessings & blessing & $\begin{array}{l}\text { salat(graces, } \\
\text { honours...) }\end{array}$ & $\begin{array}{l}\text { grace and } \\
\text { greetings }\end{array}$ \\
\hline 4.blessing & blessings & blessings & blessing & salawat & $\begin{array}{l}\text { blessings } \\
\text { and grace }\end{array}$ \\
\hline 5.religion & prayer & $\begin{array}{l}\text { (religion } \\
\text { of) prayer }\end{array}$ & $\begin{array}{l}\text { way of } \\
\text { prayer }\end{array}$ & salat(prayer) & prayer \\
\hline $\begin{array}{l}\text { 6. recitation } \\
\text { of the Qur'an }\end{array}$ & prayer & prayer & worship & salat(prayer) & prayer \\
\hline
\end{tabular}

7.synagogue synagogues synagogues oratories synagogues synagogues 
Regarding the first meaning 'prayer' used in the following verse, as Table 4 above shows, translators 1, 2 and 5 have selected the exact English equivalent.

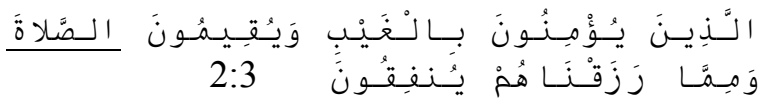

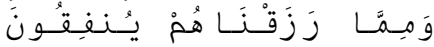

[Shakir] Those who believe in the unseen and keep up prayer and spend out of what We have given them.

[Yusuf Ali] Who believe in the Unseen, are steadfast in prayer, and spend out of what We have provided for them;

[Pickthal] Who believe in the Unseen, and establish worship, and spend of that We have bestowed upon them;

[Al-Hilali] Who believe in the Ghaib and perform As-Salât (Iqâmatas-Salât), and spend out of what we have provided for them [i.e. give Zakât, spend on themselves, their parents, their children, their wives, etc., and also give charity to the poor and also in Allâh's Cause - Jihâd, etc.].

[Saffarzadeh] (the pious are :) those who believe in the Unseen; are steadfast in performing prayers (five times daily); and spend out (to the needy) of what We have provided for them;

As regards the second meaning 'invocations', used in the following verse, Table 4 shows that only the last two translators have used the exact equivalent.
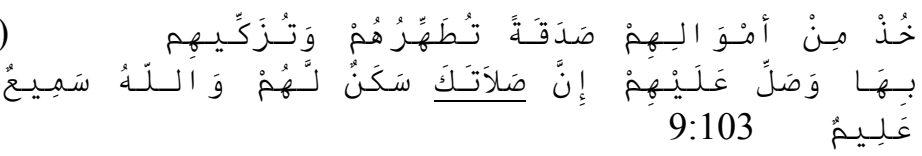

[Shakir] Take alms out of their property, you would cleanse them and purify them thereby, and pray for them; surely your prayer is a relief to them; and Allah is Hearing, Knowing. 
[Yusuf Ali] Of their goods, take alms, that so thou mightest purify and sanctify them; and pray on their behalf. Verily thy prayers are a source of security for them: And Allah is One Who heareth and knoweth.

[Pickthal] Take alms of their wealth, wherewith thou mayst purify them and mayst make them grow, and pray for them. Lo! thy prayer is an assuagement for them. Allah is Hearer, Knower.

[Al-Hilali] Take Sadaqah (alms) from their wealth in order to purify them and sanctify them with it, and invoke Allâh for them. Verily! Your invocations are a source of security for them, and Allâh is AllHearer, All-Knower.

[Saffarzadeh] (O, Messenger!)take alms from their wealth in order to purify and sanctify them by it; and pray for them to Allah; verily, your invocations are a source of tranquility for them; and Allah is the Knowing Hearer.

In the case of the third meaning 'peace' used in the following verse, as it is shown in Table 4, none of the translators has used the exact equivalent.

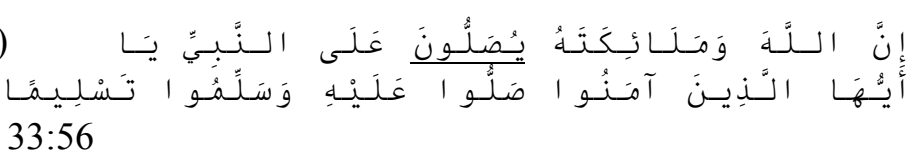

[Shakir] Surely Allah and His angels bless the Prophet; O you who believe! call for (Divine) blessings on him and salute him with a (becoming) salutation.

[Yusuf Ali] Allah and His angels send blessings on the Prophet: $\mathrm{O}$ ye that believe! Send ye blessings on him, and salute him with all respect.

[Pickthal] Lo! Allah and His angels shower blessings on the Prophet. $\mathrm{O}$ ye who believe! Ask blessings on him and salute him with a worthy salutation. 
[Al-Hilali] Allâh sends His Salât (Graces, Honours, Blessings, Mercy, etc.) on the Prophet (Muhammad) and also His angels too (ask Allâh to bless and forgive him). O you who believe! Send your Salât on (ask Allâh to bless) him (Muhammad), and (you should) greet (salute) him with the Islâmic way of greeting (salutation i.e. AsSalâmu 'Alaikum). [Saffarzadeh] verily, Allah bestows Grace and Greetings on the Messenger, and so do His angles. O, You who believe! pray that Allah's Grace be on the Messenger and salute him wholeheartedly and with full respect;

Considering the next meaning 'blessing' used in the following verse, according to Table 4, all translators but $\mathrm{T} 4$ have been successful in selecting the correct equivalent.

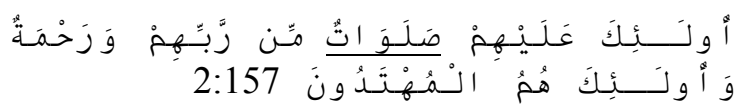

[Shakir] Those are they on whom are blessings and mercy from their Lord, and those are the followers of the right course.

[Yusuf Ali] They are those on whom (Descend) blessings from Allah, and Mercy, and they are the ones that receive guidance.

[Pickthal] Such are they on whom are blessings from their Lord, and mercy. Such are the rightly guided.

[Al-Hilali] They are those on whom are the Salawât (i.e. blessings, etc.) (i.e. who are blessed and will be forgiven) from their Lord, and (they are those who) receive His Mercy, and it is they who are the guided-ones.

[Saffarzadeh] (These patients are :) those for whom are the Blessings and Grace from their Creator\& Nurturer; and they are the guided ones indeed.

Concerning the meaning 'religion' used in the following verse, only T2 has selected the correct English equivalent. 


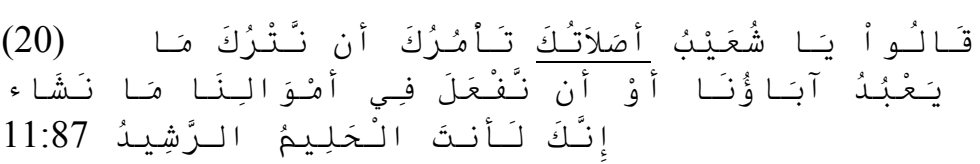

11:87

[Shakir] They said: O Shu'aib! does your prayer enjoin you that we should forsake what our fathers worshipped or that we should not do what we please with regard to our property? Forsooth you are the forbearing, the right-directing one.

[Yusuf Ali] They said: "O Shu'aib! Does thy (religion of) prayer command thee that we leave off the worship which our fathers practised, or that we leave off doing what we like with our property? truly, thou art the one that forbeareth with faults and is rightminded!"

[Pickthal] They said: O Shu'eyb! Doth thy way of prayer command thee that we should forsake that which our fathers (used to) worship, or that we (should leave off) doing what we will with our own property. Lo! thou art the mild, the guide to right behaviour.

[Al-Hilali] They said: "O Shu'aib! Does your Salât (prayer) (i.e. the prayers which you offer has spoiled your mind, so you) command that we leave off what our fathers used to worship, or that we leave off doing what we like with our property? Verily, you are the forbearer, right-minded!" (They said this sarcastically).

[Saffarzadeh] they said: "O,Shuaib! Does your prayer enjoin you that we should quit what our ancestors worshipped or that we should force ourselves not to use our own properties the way we please? Indeed you are a forbearing man of wisdom!"

Considering the meaning 'recitation of the Qur'an' used in the following verse, none of the translators has used the exact English equivalent.

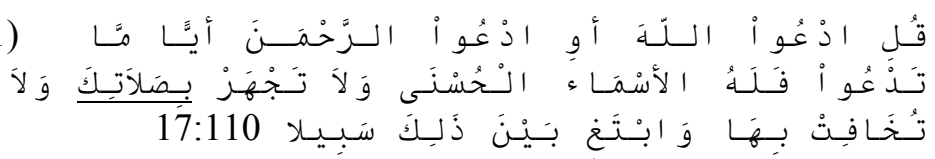


[Shakir] Say: Call upon Allah or call upon, the Beneficent Allah; whichever you call upon, He has the best names; and do not utter your prayer with a very raised voice nor be silent with regard to it, and seek a way between these.

[Yusuf Ali] Say: "Call upon Allah, or call upon Rahman: by whatever name ye call upon Him, (it is well): for to Him belong the Most Beautiful Names. Neither speak thy Prayer aloud, nor speak it in a low tone, but seek a middle course between."

[Pickthal] Say (unto mankind): Cry unto Allah, or cry unto the Beneficent, unto whichsoever ye cry (it is the same). His are the most beautiful names. And thou (Muhammad), be not loud-voiced in thy worship nor yet silent therein, but follow a way between.

[Al-Hilali] Say (O Muhammad): "Invoke Allâh or invoke the Most Beneficent (Allâh), by whatever name you invoke Him (it is the same), for to Him belong the Best Names. And offer your Salât (prayer) neither aloud nor in a low voice, but follow a way between. [Saffarzadeh] say(O,messenger!):if you invoke to Allah or to ArRahman(it is the same)since there are names of Outstanding excellence for Allah(Ar-Rahman is one of them)." And (O,Messenger!) do not say your prayer neither aloud nor with o low voice but seek a way between that.

Finally, as Table 4 shows, all translators but T3 have used the correct equivalent for the last meaning 'synagogue' used in the following verse.

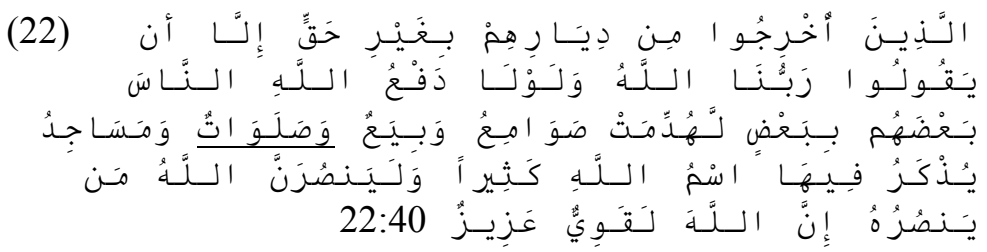

[Shakir] ... And had there not been Allah's repelling some people 
by others, certainly there would have been pulled down cloisters and churches and synagogues and mosques in which Allah's name is much remembered; and surely Allah will help him who helps His cause; most surely Allah is Strong, Mighty.

[Yusuf Ali] ... Did not Allah check one set of people by means of another, there would surely have been pulled down monasteries, churches, synagogues, and mosques, in which the name of Allah is commemorated in abundant measure. Allah will certainly aid those who aid his (cause);- for verily Allah is full of Strength, Exalted in Might, (able to enforce His Will).

[Pickthal] ... For had it not been for Allah's repelling some men by means of others, cloisters and churches and oratories and mosques, wherein the name of Allah is oft mentioned, would assuredly have been pulled down. Verily Allah helpeth one who helpeth Him. Lo! Allah is Strong, Almighty.

[Al-Hilali] ... For had it not been that Allâh checks one set of people by means of another, monasteries, churches, synagogues, and mosques, wherein the Name of Allâh is mentioned much would surely have been pulled down. Verily, Allâh will help those who help His (Cause). Truly, Allâh is All-Strong, All-Mighty.

[Saffarzadeh] ...had not Allah repelled the aggression of the disbelievers by the believers they would have destroyed monasteries, synagogues, churches and the mosques where Allah's remembrance is commemorated abundantly.

\section{5. شهبي (Shahīd)}

The last homonymous word considered in this study is the term شعيي (Shahīd). According to Teflisi (1960: 146-8) \& Penrice (1971: 72 ), this term has been used in its six different meanings in the Qur'an, i.e. prophet, present, associate, angels, followers of prophet, martyr, and witness. 
Table 5. Equivalents of the Term شهيد (Shahīd) in Five English Versions

\begin{tabular}{llllll} 
Meaning & $\operatorname{tr} 1$ & $\operatorname{tr} 2$ & $\operatorname{tr} 3$ & $\operatorname{tr} 4$ & $\operatorname{tr} 5$ \\
\hline 1.prophet & witness & witness & witness & witness(their witness
\end{tabular}

messenger)

2.present witnesses witnesses present witnesses witnesses

3.associate witnesses witnesses witnesses witnesses witnesses (supporters and helpers)

4.angels witnesses witnesses witnesses witnesses witnesses

(the messenger and the angels)

5.followers witnesses witnesses witnesses witnesses witnesses of prophet (of truth). (of the truth) 6.martyr witnesses witnesses witnesses martyr martyr 7.witness witnesses witnesses witnesses witnesses witnesses

Regarding the first meaning 'prophet', used in the following verse, Table 5 shows that only the translator 4 has selected its correct equivalent (in parenthesis).

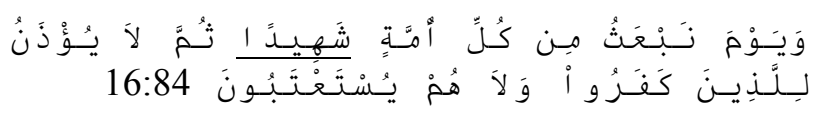

[Shakir] And on the day when We will raise up a witness out of every nation, then shall no permission be given to those who disbelieve, nor shall they be made to solicit favor.

[Yusuf Ali] One Day We shall raise from all Peoples a Witness: then will no excuse be accepted from Unbelievers, nor will they receive any favours.

[Pickthal] And (bethink you of) the day when we raise up of every 
72 A Semantic Study of the Translation of Homonymous Terms

nation a witness, then there is no leave for disbelievers, nor are they allowed to make amends.

[Al-Hilali] And (remember) the Day when We shall raise up from each nation a witness (their Messenger), then, those who have disbelieved will not be given leave (to put forward excuses), nor will they be allowed (to return to the world) to repent and ask for Allâh's Forgiveness (of their sins, etc.).

[Saffarzadeh] and on the day when We shall raise up from every nation a witness then those who have disbelieved will have no chance to express any excuse nor to ask for forgiveness to amend;

As regards the second meaning 'present', used in the following verse, Table 5 shows that only T3 has selected the exact equivalent.

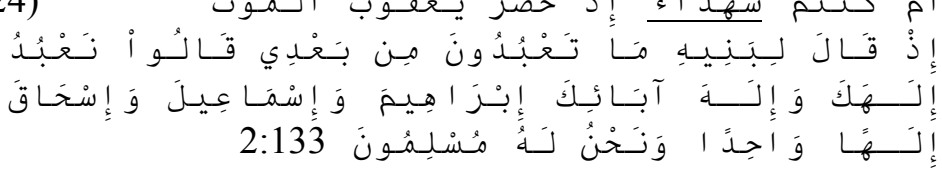

[Shakir] Nay! were you witnesses when death visited Yaqoub... [Yusuf Ali] Were ye witnesses when death appeared before Jacob? ... [Pickthal] Or were ye present when death came to Jacob?...

[Al-Hilali] Or were you witnesses when death approached Ya'qûb (Jacob)?...

[Saffarzadeh] were you witnesses when death approached Ya'qub? ...

Considering the third meaning 'associate', used in the following verse, only T4 has selected the exact equivalent (in parenthesis).

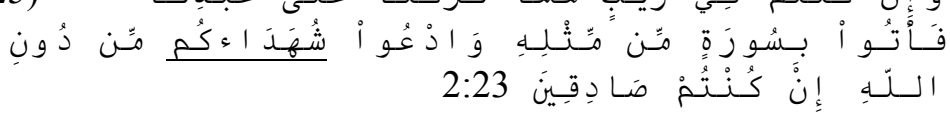


[Shakir] ....and call on your witnesses besides Allah ...

[Yusuf Ali] ....and call your witnesses or helpers (If there are any) besides Allah...

[Pickthal] ... and call your witness beside Allah ...

[Al-Hilali] ....and call your witnesses (supporters and helpers) besides Allâh...

[Saffarzadeh] ....and call your witnesses apart from Allah...

In the case of the meaning 'angels', used in the following verse, Table 5 shows that only T5 has used the exact equivalent (in footnote).
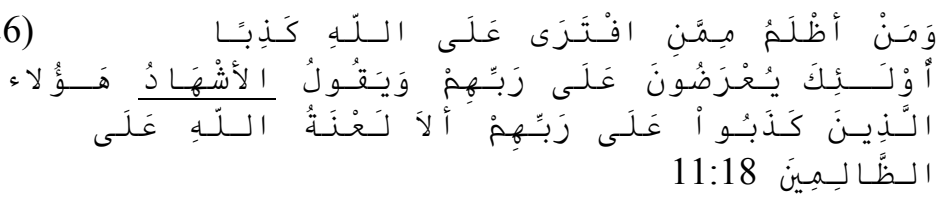

[Shakir] ....and the witnesses shall say: These are they who lied against their Lord. Now surely the curse of Allah is on the unjust.

[Yusuf Ali] ....and the witnesses will say, "These are the ones who lied against their Lord! Behold! the Curse of Allah is on those who do wrong!-

[Pickthal] ... and the witnesses will say: These are they who lied concerning their Lord. Now the curse of Allah is upon wrong-doers, [Al-Hilali] ....and the witnesses will say, "These are the ones who lied against their Lord!" No doubt! the curse of Allâh is on the Zâlimûn (polytheists, wrong-doers, oppressors, etc.).

[Saffarzadeh] ... and the witnesses ${ }^{1}$ shall say: "these are those who lied against their Creator\&Nurturer."

Regarding the next meaning 'followers of prophet', used in the following verse, none of the translators has selected the correct

1 messengers and angels 
74 A Semantic Study of the Translation of Homonymous Terms

equivalent.

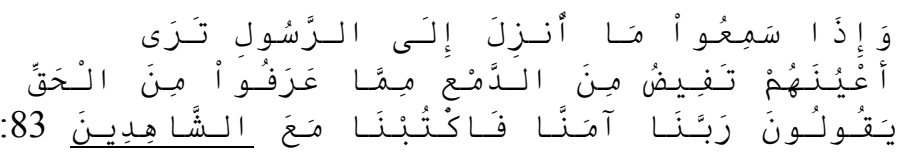

[Shakir] ...they say: Our Lord! we believe, so write us down with the witnesses (of truth).

[Yusuf Ali] ...they pray: "Our Lord! we believe; write us down among the witnesses.

[Pickthal] When they listen to that which hath been revealed unto the messengers, thou seest their eyes overflow with tears because of their recognition of the Truth. They say: Our Lord, we believe. Inscribe us as among the witnesses.

[Al-Hilali] ... They say: "Our Lord! We believe; so write us down among the witnesses.

[Saffarzadeh] ...they pray: "O,our Creator\&Nurturer!we believe,so write us down among the witnesses(of the Truth)."

In the case of the next meaning 'martyr' used in the following verse, as Table 5 shows, only translators 4 and 5 have selected the correct equivalent.

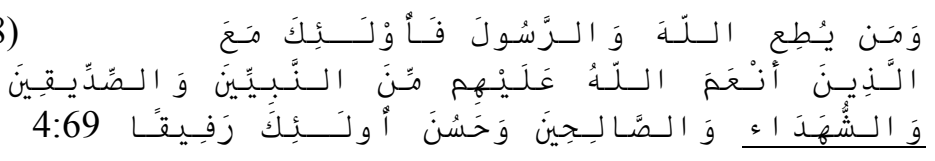

[Shakir] ...from among the prophets and the truthful and the martyrs and the good, and a goodly company are they!

[Yusuf Ali] of the prophets (who teach), the sincere (lovers of Truth), the witnesses (who testify), and the Righteous (who do good): Ah! what a beautiful fellowship!

[Pickthal] ...of the prophets and the saints and the martyrs and the 
righteous. The best of company are they!

[Al-Hilali] ... of the Prophets, the Siddiqûn (those followers of the Prophets who were first and foremost to believe in them, like Abu Bakr AsSiddiq), the martyrs, and the righteous. And how excellent these companions are!

[Saffarzadeh] ...such as the Prophets, the truthful,the martyrs and the righteous; and how excellent are these companions;

Finally, all translators have used the exact English equivalent for the last meaning 'witness', used in the following verse.

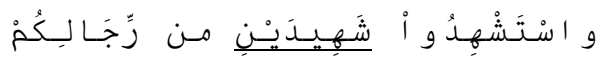

[Shakir] and call in to witness from among your men two witnesses [Yusuf Ali] and get two witnesses, out of your own men

[Pickthal] And call to witness, from among your men, two witnesses. [Al-Hilali] And get two witnesses out of your own men. [Saffarzadeh] and call to witness,two witnesses from among your men....

\section{Results and Conclusion}

The present study sought to scrutinize five English translations of a number of Qur'anic homonyms, i.e. سما (Samā'), دعاa (Dū') فتح (Fath), , شعيد (Shalât), and ) to see in what ways the translators have tackled the problems arising from the transference of such semantic items characterizing sacred texts. The results of the study are presented in Table 6 below: 
76 A Semantic Study of the Translation of Homonymous Terms

Table 6. Equivalents of Five Qur'anic Terms in Five English Translations

\begin{tabular}{|c|c|c|c|c|c|}
\hline Ieaning & $\operatorname{tr} 1$ & $\operatorname{tr} 2$ & $\operatorname{tr} 3$ & $\mathrm{tr} 4$ & $\operatorname{tr} 5$ \\
\hline Sky & heaven & heaven & heaven & heaven & heaven \\
\hline oud & clous & sky & & sky & ky \\
\hline in & oud & rain & sky & rain & rain \\
\hline & eiling & ceiling & roof & ceiling & eiling \\
\hline ay & cry & cry & prayer & $\begin{array}{l}\text { their way of } \\
\text { request }\end{array}$ & prayer \\
\hline orship & call & call & cry & oke & worship \\
\hline & $\mathrm{ca}$ & call & call & call & call \\
\hline eking & call & call & call & & $\mathrm{c}$ \\
\hline king & all on & beseech & pray & call upon & beseech \\
\hline questing & pray & & pray & invoke & pray \\
\hline $\begin{array}{l}\text { resurrection } \\
\text { day }\end{array}$ & & $\begin{array}{l}\text { day of } \\
\text { decision }\end{array}$ & $\begin{array}{l}\text { day of the } \\
\text { victory }\end{array}$ & $\begin{array}{l}\text { day of al-fath } \\
\text { (decision) }\end{array}$ & day of victoty \\
\hline to judge & judge & decide & judge & judge & judge \\
\hline 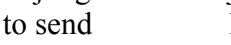 & let loose & let through & let loose & let 1 & let loose \\
\hline open & be opened & be opened & be opened & be opened & be opened \\
\hline help & victory & victory & victory & victory & victory \\
\hline ray & pra & praye & worship & al-si & prayer \\
\hline ns & $\mathrm{pr}$ & pray & pras & inve & invoc \\
\hline (2) & $\mathrm{bl}$ & bles & bles & $\begin{array}{l}\text { salat }(\mathrm{g} \\
\text { honour }\end{array}$ & $\begin{array}{l}\text { grace and } \\
\text { greetings }\end{array}$ \\
\hline blessi & blessii & blessings & bless & salawat & $\begin{array}{l}\text { blessings and } \\
\text { grace }\end{array}$ \\
\hline religion & prayer & $\begin{array}{l}\text { (religion } \\
\text { of) prayer }\end{array}$ & $\begin{array}{l}\text { way of } \\
\text { prayer }\end{array}$ & salat(prayer) & prayer \\
\hline Qur'a & pra & prayer & worship & salat(prayer) & prayer \\
\hline $\begin{array}{l}\text { synagogue } \\
\text { prophet }\end{array}$ & $\begin{array}{l}\text { synagoguc } \\
\text { witness }\end{array}$ & $\begin{array}{l}\text { synagogues } \\
\text { witness }\end{array}$ & $\begin{array}{l}\text { oratories } \\
\text { witness }\end{array}$ & $\begin{array}{l}\text { synagogues } \\
\text { witness(their } \\
\text { messenger) }\end{array}$ & $\begin{array}{l}\text { synagogues } \\
\text { witness }\end{array}$ \\
\hline pres & & & & witn & \\
\hline & & Witı & witn & $\begin{array}{l}\text { Witnesses } \\
\text { (supporters and } \\
\text { helpers) }\end{array}$ & witne \\
\hline angels & witnesses & Witnesses & witnesses & witnesses & $\begin{array}{l}\text { Witnesses } \\
\text { (messenger\& } \\
\text { angels) }\end{array}$ \\
\hline $\begin{array}{l}\text { followers of } \\
\text { prophet }\end{array}$ & $\begin{array}{l}\text { witnesses } \\
\text { (of truth). }\end{array}$ & Witnesses & witnesses & witnesses & $\begin{array}{l}\text { witnesses(of } \\
\text { the truth) }\end{array}$ \\
\hline & & & witne & & martyr \\
\hline & witnesses & witnesses & witnesses & witnesses & witnesses \\
\hline
\end{tabular}


As Table 6 above and Table 7 below show, translators 4 (Mohammad Al-Hilali) and translator 5 (Tahereh Saffarzadeh) have succeeded the most in selecting the correct English equivalents for the chosen homonyms of the Qur'an, thus disambiguating the related texts more than others. However, this does not mean that other translators have mistranslated the above-mentioned homonyms. It may rather mean that they have rendered the primary sense of words, i.e. the first and immediate sense suggested by each word, without having attended to contextual clues. In other words, they have ignored the secondary sense of the homonymous words which best fits the context in which they occur.

Table 7. Frequency of Correct Equivalents

Translator Frequency of Correct Equivalents Used by Each Translator

1

2

3

4

5
12

11

9

15

15

Such examples of homonymous terms and ambiguity resulting from their translation show that there is no one-to-one relationship between sounds and meanings in any two languages and, therefore, we can not always derive the precise meaning of a term from its sounds alone. What is needed, therefore, is a context in which the words, phrases, and sentences occur. This issue is predominantly the case in the translation of sacred religious texts; the Qur'an in particular, in which words usually have surface as well as deep meanings. The translators of such texts have to keep in mind that the primary or superficial meanings of terms are not basically the intended meaning. They must therefore make a great deal of efforts to realize the exact intended meaning of terms as far as possible and transfer them to the target language in a transparent manner. 
Ambiguity resulting from homonymous terms of the source text may be conscious or unconscious. This binds the translator to a twofold responsibility. In the former case, it is the translator's job to reproduce and retain the intended ambiguity in the translated text. Unconscious ambiguity, on the other hand, has to be clarified and disambiguated according to the situational or linguistic context. In such cases, the translator's job is to sacrifice the less important meaning or, according to Newmark (1988), "appending the less likely meaning if there is the slightest possibility of it being the correct one" (25).

A final word here is that religions texts, including the word of God (such as the Quran), are the texts which have been repeatedly translated in the course of their history makes it quite clear that the new generation of translators have always thought of some sort of ambiguity, semantic or otherwise, in the works of their predecessors, and have thus tried to reduce it to the extent possible. This ambiguity arises from the nature of religious texts which are subject to their contexts within the community, rather than their semantic contexts for their understanding (Shackle 2005). In fact, the ambiguity imposed on the translator in rendering sacred texts is different from what is resulted from non-sacred texts translation, in that the former is a matter of both 'contexts of culture', e.g. cultural associations of the Quranic expressions in the present research, and 'contrasting interpretations' by different scholars.

\section{References}

Al-Hilali, M. \& M. Khan. 1995. The Noble Qur'an: English Translation of the Meaning and Commentary. Madinah: K.S.A.

Ali, A. 1990. The Meanings of the Holy Qur'an. New Delhi: Kitab Bhavan.

Carter, R. et al. 1997. Working With Texts: A Corebook for Language Analysis. London: Routledge. 
Empson, W. 1961. Seven Types of Ambiguity. Great Britain: Penguin Books.

Fromkin, V. \& R. Rodman. 1988. An Introduction to Language. Los Angeles, CA: University Of California.

Newmark, P. 1988. A Textbook for Translation. London: Routledge. Palmer, F. 1970. Semantics. Cambridge: Cambridge University Press.

Penrice, J. 1971. A Dictionary and Glossary of the Koran. London: Curzon Press.

Pickthall, M. 1990. The Meaning of the Glorious Qur'an. New Delhi: Kitab Bhavan.

Saffarzadeh, T. 2001. The Holy Qur'an: English \& Persian Translation with Commentary. Tehran: Honar Bidari Publisher.

Salehi, M. 1996. A Linguistic Approach toward the Qur'an: Literary Patterns-(Un)Translatabilities. Tehran: Imam Hossein University Publisher.

Shackle, Ch. 2005. From Gentlemen's Outfitters to Hyperbazaar: A Personal Approach to Translating the Sacred. In L. Long (ed.), Translation and Religion: Holy Untranslatable? 19-32. London: Multilingual Matters.

Shakir, M. 1985. The Holy Qur'an. Newyork: Tahrike Tarsile Qur'an.

Teflisi, A. 1960. Semantic Aspects of the Holy Qur'an. Tehran: SAMT.

Yule, G. 1996. The Study of Language. Cambridge: Cambridge University Press. 